This is the version of the article accepted for publication in Arab Law Quarterly published by Brill:

http://booksandjournals.brillonline.com/content/journals/15730255

Accepted version downloaded from SOAS Research Online: http://eprints.soas.ac.uk/29952

\title{
Islamic Financial Law and the Law of the United Arab Emirates: Disjuncture and the Necessity for Reform Jonathan Ercanbrack, SOAS University of London
}

\begin{abstract}
Islamic financial law (IFL), an emerging global legal order, is a highly fragmented law comprised of both state and non-state generated laws, standards, commercial practices, institutions, fatwas and legal ideas. A recent event involving a Sukuk issuance in which Dana Gas claimed that its sukuk were no longer sharia-compliant highlights the legal disjuncture between the global IFL and the laws of municipal legal systems, which have chosen to facilitate and regulate Islamic finance. Systemic legal issues or "legal gaps" undermine investor confidence and impede sustainable development of the Islamic finance industry. Legal gaps include but are not limited to undeveloped securities laws, enforceability issues and a lack of clarity with respect to the role and effect of the sharia in the municipal legal systems of many MENA states. This paper analyses these gaps and in so doing illustrates the relationship of IFL to the law of the United Arab Emirates.
\end{abstract}

\section{Keywords}

Islamic finance; transnational law; standardisation; sharia; legal transplant; sukuk

Islamic financial law (IFL) is a highly fragmented global legal order, which is generated in the interaction of legal systems and the global transposition of standards, rules, fatwas and legal ideas in modern financial markets. ${ }^{1}$ IFL is the law used to structure Islamic financial transactions in over 70 municipal legal systems worldwide. While possessing legal characteristics similar to those of jurisdictions or national legal systems, IFL cannot be understood solely according to the standards of such systems as its sources are not limited to those of traditional lawmaking. IFL encompasses diverse sources of law, regulatory standards, commercial practices, institutional transplants, fatwas and ideas, whether these are borrowed from nation states or from non-state actors including multinational financial institutions, international standard setting bodies, international law firms or sharia scholars. ${ }^{2}$

\footnotetext{
*I would like to especially thank Sara Cattarin for her very generous expenditure of time and effort. I would also like to thank Iqbal Asaria, Raj Brown and an anonymous reviewer for their very helpful suggestions and criticism.

${ }^{1}$ The first effort to conceptualise IFL is found in Nicholas Foster, 'Islamic Finance Law as an Emergent Legal System', Arab Law Quarterly 21 (2007): 170-188. A subsequent book, which sought to develop Foster's ideas is Jonathan Ercanbrack, The Transformation of Islamic Law in Global Financial Markets (Cambridge: CUP, 2015).

${ }^{2}$ Almost all countries have a formal legal order or system in today's world, which embodies codes or court cases which have been developed by designated state organs or institutions responsible for formulating and enforcing law. Yet this is just one element of the governance structure of society. Many informal norms and institutions govern most societies. The positivist view of law that rules formulated and enforced by the state are the only sources of law neglects the enforcement of rules which are formulated elsewhere whether these derive from scholarly writing, manuals, or university teaching. See Rodolfo Sacco, 'Legal Formants: A Dynamic
} 
Unlike most legal transplants, ${ }^{3}$ IFL does not originate solely or even primarily in a specific municipal legal system. On the contrary, it is formulated and transposed via the process of globalisation. It is a process-oriented mode of lawmaking, which challenges traditional conceptual and analytical frameworks of law, theories of legal harmonisation, the classification of legal families and, indeed, the concept of the legal system itself.

The hybridised nature of IFL has seldom been the focus of academic analysis not to mention amongst industry circles, possibly for the reason that it problematises the sharia authenticity of the IFL and the industry that it underpins. Hybridity highlights the fact that the sharia is the subject of innovation in financial markets, constitutes just one element of IFL, and is easily distinguished from classical notions of the sharia. ${ }^{4}$ Few authors conceptualise this transformation, perhaps because the sharia is considered immutable. It is the word of God as revealed by the Prophet Muhammad and therefore humanity should not modify or tamper with it. The fact that the IFL represents a modern transformation of sharia principles challenges this belief. The sharia must be reconceptualised as a man-made system of law, which throws into question its sharia authenticity. It shifts the discourse from the classical

Approach to Comparative Law' (1991) 29 No. 2 American Journal of Comparative Law 343-401, 344. Historically, informal legal orders have been seen to have developed from the existing norms of various social groups. See Daniel Berkowitz, Katharina Pistor, Jean-Francois Richard, 'Economic Development, Legality and the Transplant Effect', European Economic Review 47 (2003): 165-195. Moreover, the globalisation of socioeconomic processes requires a reconceptualisation of lawmaking, and the generation of global law, in particular, as worldwide 'technical standardisation and professional self-regulation' have developed alongside and sometimes in interaction with the lawmaking processes of formal legal orders. The literature in support of these ideas is voluminous. Excellent examples are: Günther Teubner, 'Global Bukowina': Legal Pluralism in the World Society. Global Law Without A State' (Aldershot: Dartmouth Publishing Company, 1997). And: Boaventura Sousa Santos, Toward a New Common Sense, (New York: Routledge, 1995). Moreover, there is a large body of literature concerning the lex mercatoria and its modern variants. The lex mercatoria is a global legal order comprised of worldwide commercial practices, unitary directives, standardized contracts, international standards, codes of conduct and the decisions of arbitral courts. A good start is: Ralf Michaels, 'The True Lex Mercatoria: Private Law Beyond the State' Indiana Journal of Global Legal Studies 14 (2007): 447-468.

${ }^{3}$ The transfer of a legal rule from one jurisdiction to another - a so-called legal transplant - is an old experience for many jurisdictions, particularly those in developing countries including most states in the MENA region. The term "legal transplant", however, is perhaps not the most suitable term to describe IFL because the facilitation of IFL in municipal legal systems has developed via the socioeconomic processes of globalisation. IFL does not originate solely from any specific jurisdiction as most literature dealing with legal transplants specifies. The origins of IFL are global even though individual states such as Malaysia and Bahrain have undertaken enormous efforts in developing industry specific legal and regulatory frameworks. These states too have borrowed from the practices and standards of international non-state actors in formulating their legal systems. The concept of 'legal transposition' is a more encompassing concept of legal borrowing, which has been used to indicate that 'the movement of legal institutions and ideas is trans-border and such transmigration is a natural phase in legal development'. See Esin Örücü, 'Law as Transposition', The International and Comparative Law Quarterly 51 (2) (2002): 205-223, 222. Also, Esin Örücü, 'A Theoretical Framework for Transfrontier Mobility of Law' in R Jagtenberg et al (eds.), Transfrontier Mobility of Law (The Hague: Kluwer Law International, 1995). With these differences in mind, the principle that law is borrowed, irrespective of its origins, is common to both ways of describing legal change.

${ }^{4}$ Hybridised legal orders such as IFL reflect the interaction of pluralistic normative orderings, whether these are state law, religious law or international financial standards in a particular historical context. IFL can be easily distinguished from the traditional law of nation states including "mixed" legal systems. For example, "mixed Law" scholarship does not dispute the legal pluralism of every existing legal system. However, it places greater theoretical emphasis on understanding the interaction of established legal families whereas legal pluralism is concerned with all types of normative orderings. Mixed law scholarship also makes initial assumptions concerning its categorisation of legal families as "pure" or "mixed", etc. Its objective is to locate the elements of legal interaction and try to understand how these elements affect the original legal family. 
fiqh to the IFL, which, in turn, highlights Islamic financial practices which may not live up to Islamic principles.

A default scenario involving a global sukuk may finally frustrate the long-held reticence to deal squarely with the way in which Islamic law has been transformed in global financial markets. In 2017, Dana Gas, a United Arab Emirates (UAE) energy company, told investors that it could not make payments on its $\$ 700 \mathrm{~m}$ sukuk issuance because the underlying structure was no longer sharia-compliant. The company filed a motion in the UAE courts which seeks to declare the mudaraba sukuk unlawful under UAE law. It also obtained injunctions in the UAE court and the English court, prohibiting investors from taking any action under the mudaraba agreement or the purchase undertaking until a final decision was reached in those proceedings. ${ }^{5}$ Dana Gas sought to restructure the $\$ 700 \mathrm{~m}$ issuance so that profit distributions were halved on the grounds that the structure had become unlawful 'due to the evolution and continual development of Islamic financial instruments and their interpretation'. ${ }^{6}$ The announcement set an odious precedent since other firms could seek to escape their debt obligations by claiming sharia non-compliance. The case threatened to undermine confidence in the industry.

Dana Gas's claim that its sukuk were no longer sharia compliant highlights the legal and regulatory gaps that exist between the IFL and the municipal legal systems in which Islamic finance is facilitated. Most countries, which facilitate Islamic finance, have adopted civil or common law legal systems and do not possess the legal and regulatory infrastructure to adequately regulate and enforce Islamic finance transactions. There are several notable reasons for this. First, as noted above, IFL is a hybridised system of law and almost certainly requires industry specific legal and regulatory infrastructure for it to function effectively and safely. Second, it is rarely observed that the hybridity of IFL is partly a reflection of the hybrid legal systems in which Islamic finance is normally facilitated. Islamic finance transactions comprise legal aspects that are meant to function according to different systems of law but which are amalgamated in a single transaction. The Dana Gas Sukuk is a case in point. Third, the hybridity of IFL and many of the municipal legal systems in which Islamic finance is facilitated underscore the uncertain role of the sharia in otherwise secular legal systems. The desire of the lawmaker in many of these jurisdictions to give effect to the sharia, while also creating modern, uniform systems of law, has resulted in considerable legal ambiguity. Using the Dana Gas Sukuk issuance as a case study, this paper analyses these issues in one of the most important facilitating states for the Islamic finance industry, the UAE. $^{7}$

A number of systemic legal issues or "legal gaps" undermine investor confidence and impede sustainable development of the Islamic finance industry. Legal gaps include but are not limited to: undeveloped securities laws; enforceability issues; and a lack of clarity with respect to the role and effect of the sharia in the municipal legal systems of many MENA states. More generally, these highly complex legal environments are associated with a reduced flow of information (lack of transparency), which results in diminished legal certainty and foreseeability. ${ }^{8}$

\footnotetext{
${ }^{5}$ Dana Gas PJSC v. Dana Gas Sukuk Ltd [2017] EWHC 2340 (Comm).

${ }^{6}$ Dana Gas, 'Dana Gas Outlines Broad Terms for Sukuk Discussions' (UAE, 13 June 2017).

${ }^{7}$ In 2016, 8.1 per cent of global Islamic banking assets were held in the UAE. See Islamic Financial Services Board, 'Islamic Financial Services Board Stability Report 2016' (IFSB, 2016) < http://www.ifsb.org/docs/IFSI\%20Stability\%20Report\%202016\%20(final).pdf>, accessed 18 September 2017.

${ }^{8}$ Ghiath Shabsigh et al., 'Ensuring Financial Stability in Countries with Islamic Banking' (International Monetary Fund, IMF Country Report No. 17/145, 2017) pp. 1-43.
} 
Legal systems represent a complex interdependence of legal rules, institutions and concepts which generally can only be understood in relation to other rules, institutions or concepts. Law is a cognitive institution. The effectiveness of its rules is predicated on social actors' knowledge and understanding of the key elements and underlying values of the legal order. Even though most members of society do not have familiarity with individual rules and regulations, they do understand the basic concepts of the legal system. Further, they are able to rely on legal professionals, who have an advanced understanding of the legal order. Yet even professionals must understand the wording of the rule, its underlying concept and value judgments as well as its position within the legal order to be able to apply a particular rule or regulation. ${ }^{9}$ While it has been argued that 'law possesses a life and vitality of its own' and that 'no extremely close, natural or inevitable relationship exists between law, legal structures, institutions and rules on the one hand and the political economy of the ruling elite or of the members of the particular society on the other hand', recent empirical evidence indicates a more nuanced picture. ${ }^{10}$ Complementarities do exist among different institutions within a society and the piecemeal modification of a national system can have important implications. ${ }^{11}$ This is not to claim, as some notable authors have done, that the transfer of a legal rule from one jurisdiction to another is impossible, at worst, or ineffectual, at best. Accordingly, a particular socio-cultural understanding of a rule underlies its formulation, so that its transplantation is indecipherable to those whose language, tradition and culture are different than the one in which the rule was conceived. ${ }^{12}$ Transplantation of law has taken place throughout history in much of the world and the result has often been satisfactory, even beneficial. ${ }^{13}$ For example, the demise of the Soviet Union led to its former socialist satellites adopting legal codes in full, which enabled them to quickly reform their legal systems. While rapid reform clearly entailed a number of important advantages in the political and legal vacuum left in the wake of the Soviet Union, the enforcement of the transplanted law has been problematic. The law on the books is often different than the law in action. The context specificity of law indicates that in situations in which the meaning of specific legal rules or institutions are not apparent, they may not be applied or may be applied in a way that is inconsistent with the objective of the rule in the context in which it originated. This in turn affects the legitimacy and trustworthiness of the institutions charged with applying such rules. ${ }^{14}$ The legal transplant can become a legal irritant, one which 'triggers a whole series of new and unexpected events' and which creates 'wild perturbations in the interplay of discourses within these arrangements and forces them to reconstruct internally not only their own rules but to reconstruct from scratch the element itself.' ${ }^{15}$ However, evidence also indicates that when the transplanted law is adapted to meet local needs, its effectiveness is greater as there is greater readiness to allocate resources to enforce and develop the legal order. A further means of shoring up the effectiveness of the

\footnotetext{
${ }^{9}$ Berkowitz et al., supra note 5 at 166.

${ }^{10}$ Alan Watson, 'Comparative Law and Legal Change’ 37 (2) (1978) Cambridge Law Journal: 313-336, 315.

${ }^{11}$ Dani Rodrik, 'Institutions for High Quality Growth: What They Are and How to Acquire Them' 35 (2000)

No. 3 Studies in Comparative International Development: 3-31, 9.

${ }^{12}$ Pierre Legrand, 'The Impossibility of Legal Transplants' 4 (1997) Maastricht Journal of European \& Comparative Law: 111-124, 115.

${ }^{13}$ The French Civil Code is the most heavily transplanted legal code in the modern period, having been transplanted to Quebec, Louisiana, South America, much of Africa, the Middle East, and elsewhere. The British Empire exported the common law to Canada, the United States, Australia, New Zealand, India and elsewhere.

${ }^{14}$ Berkowitz et al., supra note 5 at 174.

${ }^{15}$ Günther Teubner, 'Legal Irritants: Good Faith in British Law or How Unifying Law Ends Up in New Divergences’ 61 (1998) Modern Law Review: 11-32, 12.
} 
transplanted law is to ensure that the transplant possesses common roots or a common legal history so that major adaptations to the law are not necessary. ${ }^{16}$

Therefore, the transposition of IFL to formal legal orders is more effective when bodies of complementary law in the receiving legal systems already exist. Alternatively, receiving legal systems will need to undergo reform so that complementarity exists between the new law and pre-existing legal institutions. ${ }^{17}$ Many legal and regulatory gaps in the municipal legal systems which facilitate Islamic finance have been highlighted in legal blogs and a few scholarly articles. ${ }^{18}$ The default event of the Dana Gas sukuk illustrates gaps in UAE law where a disjuncture or absence of law exists between the IFL and UAE law. Remarkably, it also shows how UAE legal authorities have begun to reform existing gaps. The central bank of the UAE recently adopted Accounting and Auditing Organization for Islamic Financial Institutions (AAOIFI) sharia standards, illustrating a very important example of legal borrowing. From 1 September 2018 all Islamic banks, Islamic windows (of conventional banks) and finance companies offering sharia compliant products and services are required to comply with AAOIFI sharia standards. ${ }^{19}$ The new regulation does not affect sukuk issuances, so long as these are not issued by Islamic financial institutions or companies dealing in Islamic financial products or services. The reform, while important for standardising the domestic financial services industry, does not apply to cross-border sukuk issuances such as the Dana Gas Sukuk. Nor does the regulation require UAE courts to bind themselves to AAOIFI standards when adjudicating Islamic financial disputes. The following analysis demonstrates that legal gaps, including the role and effect of the sharia in UAE law, continue to undermine investor confidence in this important Islamic capital market.

\footnotetext{
16 Berkowitz et al., supra note 5 at 174-180.

${ }^{17}$ Ghiath Shabsigh et al., supra note 10 at 22.

${ }^{18}$ See Michael J.T. McMillen, 'Islamic Capital Markets: Developments and Issues', Capital Markets Law Journal 1 (2006): 136-172. McMillen provides a rare and important analysis of the 'market fragmentation' in the 'Islamic Economic Sphere' more generally. Market fragmentation affects all cross-border investment including cross border Islamic capital markets. McMillen's analysis does not conceptualise the hybridity of IFL or the ways in which its hybrid nature is partly attributable to these legal gaps. Likewise, in Michael J.T. McMillen, 'Islamic Shari'ah-Compliant Project Finance: Collateral Security and Financing Structure Case Studies', Fordham International Law Journal 24 (2000): 1184-1263. McMillen highlights the legal differences between Islamic concepts of security or collateral in Saudi Arabia and ways in which large international project financings can be structured to meet both sharia and western financial principles. In Omar Salah, 'Dubai Debt Crisis: A Legal Analysis of the Nakheel Sukuk', Berkeley J Intl L Publicist 4 (2010): 19, Salah highlights some of the legal and regulatory gaps of the UAE legal system in relation to the Nakheel Sukuk default event. His analytical focus, however, does not emphasise these gaps. Nor does Salah conceptualise IFL as a legal transplant, which requires municipal legal reform. Another is Sweder van Wijnbergen \& Sajjad Zaheer, 'Sukuk Defaults: On Distress Resolution in Islamic Finance' (Duisenberg School of Finance - Tinbergen Institute, 2013) pp. 1-51. Van Wijnbergen's and Zaheer's essay focuses on the asset based legal structure of recent sukuk defaults, arguing that this generalised structure fails investors and does not meet the standards of classical sharia. The analytical focus is not concerned with legal gaps because the IFL is not conceptualised as a distinctive legal system requiring municipal legal reform. A number of newsletters and blogs highlight similar legal issues but do not conceptualise these in relation to the IFL more generally. See Nabil Issa, 'Local Law Obstacles to Structuring an Islamic Financing in the UAE and Saudi Arabia', in Taking Stock and Moving Forward: the State of Islamic Finance and Prospects for the Future (White Paper: Hawkamah and American Bar Association 2010) pp. 31-36; Alan Rodgers, 'UAE Laws and Islamic Shari'ah: Some Practical Issues', ibid., pp. 28-29.

${ }^{19}$ Accounting and Auditing Organization for Islamic Financial Institutions, ‘AAOIFI Welcomes UAE's Adoption of Its Standards' (AAOIFI, n.d.) < http://aaoifi.com/announcement/aaoifi-welcomes-uaes-adoption-ofits-standards/?lang=en> Accessed 16/10/2018.
} 
These arguments are addressed by first analysing the role of the sharia in the UAE. Second, sukuk including the mudaraba sukuk, which was used to structure the Dana Gas Sukuk, are analysed. Third, the use of multiple governing laws in sukuk issuances is discussed. Fourth, the legal conflict between UAE civil law and the purchase and sale undertakings of the Dana Gas Sukuk structure, which were governed by English law, highlight a particularly important legal gap in UAE law. Fifth, the ramifications of the above are illustrated with respect to unperfected security interests. Sixth, other legal gaps are addressed including the absence of securitisation law in the UAE and its non-recognition of the trust. Finally, some concluding remarks are offered.

\section{The Role of the Sharia in Municipal Legal Systems}

The influence of the sharia in the mostly secular municipal legal systems of many Muslim majority states is not clearly defined or consistent. The municipal legal systems of the MENA region are hybrid legal systems mostly derived from European civil and common law systems as well as aspects of the sharia. The influence of the French Civil Code is particularly evident. ${ }^{20}$ Across the region, the sharia generally occupies a highly circumscribed role in family and inheritance law whereas its influence in other areas of law is inconsistent and sometimes absent. ${ }^{21}$ Similar to neighbouring states, the legal systems of the UAE are highly complex. Uniquely, UAE law provides a clear example of the hybridity which in many ways mirrors the hybrid attributes of Islamic financial transactions.

A federation of seven emirates, the legal system of the UAE is based on the 1971 constitution. Individual emirates have sovereignty over their own territories with respect to matters not stipulated in the constitution. UAE law, which is applicable throughout the seven emirates, is modelled on Egyptian, Sudanese and other Arabic countries. For its part, Egyptian law derives from Napoleonic or French civil and penal codes as well as sharia. Sudanese law comprises a mixture of sharia and English common law. ${ }^{22}$

The UAE constitution provides that Islam is the official religion of the union and that the sharia 'shall be a main source of legislation in the Union', which indicates that the sharia is only one source amongst others including federal law, general legal principles and customary rules. ${ }^{23}$ However, article 2 of the 1985 Federal Civil Code provides that: 'The rules and principles of Islamic jurisprudence (fiqh) shall be relied upon in the understanding, construction and interpretation of these provisions'. The Civil Code elevates the role of the sharia from ' $a$ ' source of interpretation as provided for in the constitution to 'the' source of

\footnotetext{
${ }^{20}$ Herbert J. Liebesny, 'British Jurisdiction in the States of the Persian Gulf', Middle East Journal 3 (1949): 330-332. In the late $19^{\text {th }}$ century the sharia was largely abandoned in favour of European law codes, mainly from France. Upon independence many states in the MENA region adopted the Egyptian or Kuwaiti law codes but these were derived from European civil law influences, primarily the French Civil Code. In particular, the Egyptian Civil Code of 1948 influenced the civil codes of many Arab countries. See David Suratgar, 'The Development of the Legal Systems of the Middle East; Islamic Law and the Importance of Civil Law to the Process of Modernisation', in Brian Russell (ed.), An Introduction to Business Law in the Middle East (New York: Drake Publishers, 1975), 9.

${ }^{21}$ In the $19^{\text {th }}$ century, Islamic criminal law was replaced by Western-style legal codes. The only exception to this general pattern was Saudi Arabia, which continued to apply Islamic penal law including hadd penalties.

However, in the second half of the twentieth century a number of states reintroduced codified versions of Islamic criminal law including: Libya (1972-1974); Pakistan (1979); Iran (1979); Sudan (1983); and some states in northern Nigeria (2000). See Rudolph Peters, Crime and Punishment in Islamic Law: Theory and Practice from the Sixteenth to the Twenty-First Century (Cambridge: Cambridge University Press, 2005).

${ }^{22}$ Central Intelligence Agency, 'The World Factbook' (CIA, 27 July 2017)

<https://www.cia.gov/library/publications/the-world-factbook/geos/su.html> accessed 16 August 2017.

${ }^{23}$ Constitution of the United Arab Emirates, Art. 7.
} 
law with respect to the interpretation of civil laws. Furthermore, the role of the sharia in the Civil Code is further entrenched in article 27, which provides that 'it shall not be permissible to apply the provisions of a law specified by the preceding articles if such provisions are contrary to Islamic Shari'a, public order, or morals $[\ldots] .{ }^{24}$ These provisions generate uncertainty because of their potential conflict with the constitution, the supreme source of law, and the way in which a court will interpret them. This is not made simpler by the fact that various provisions of the Civil Code contravene widely held interpretations of the sharia. For example, article 1026 permits conventional insurance, which is generally viewed as contravening the prohibition of gharar (uncertainty) or maysir (speculation) as well as dealing in riba (interest).

This lack of clarity is compounded by the diverse range of interpretations of what constitutes the sharia. Islamic law is not a polished, unequivocal statement of law. It is often more easily understood as a method. No final arbiter of religious law exists, unlike the Christian and Jewish traditions, since the Islamic legal tradition is non-hierarchical. The veracity or validity of a legal ruling resides in the erudition and religious authority of the jurists who issue such rulings. Traditionally, a legal ruling is accorded greater weight in relation to the proximity with which the issuing jurist was associated with the Prophet Muhammad and his 'rightly guided' caliphs (khulafa'u rashidun). A legal ruling or fatwa is contingent or probable, because human interpretation of God's law is fallible. What is important is the effort exerted in extracting the law from the holy sources (ijtihad) according to the practice of a particular school doctrine. The paucity of authority and the interpretive methodology of deriving law (usul al-fiqh) results in an enormous diversity of legal rulings. This diversity is evident in the number of school traditions. The Sunnis comprise the Hanafi, Shafi'i, Maliki and Hanbali schools. The Shia legal traditions include the Twelvers (Imami) from which Jafari jurisprudence is derived; but also, the Ismaili; the Druze; and the Zaidi. A final sect that is now mostly extinct is known as the Kharijites. The Ibadi remain an active denomination of this school.

UAE lawmakers have chosen to selectively apply the sharia as evidenced in Article 1 of the amended Civil Code, which excludes the applicability of the sharia in the Commercial Code. Yet this has only made matters more complex, because the Civil Code comprises the law of obligations including contract and tort. Specifically, the Civil Code comprises numerous nominate and innominate contracts including the ijara, istisna, salam and mudaraba contracts. ${ }^{25}$ Therefore, should parties elect to use a nominate or innominate contract as provided for in the Civil Code, there were seen to be a legal requirement that the fiqh is applied to the commercial matter.

\footnotetext{
${ }^{24}$ UAE Civil Code, Art. 27.

${ }^{25}$ Islamic contract law is categorised according to nominate and innominate contracts. Nominate contracts are a set of contracts in which jurists developed specific names and concise rules. Yet the basic concept of contracting unspecified for the reason that Islamic fiqh (jurisprudence) is casuistic and not dogmatic. The jurist's casuistic approach was inclined to elicit subtle rules pertaining to specific contracts rather than formulating broad theories such as a general theory of obligations. The majority of scholars instead focused on the contract of sale as a kind of model for contracts. A sale contract is generally defined as an immediate exchange of counter-values by words or deed. The focus is on the subject matter of the contract as opposed to any obligation to which the contract gave rise. However, in practice the system was much more varied. The exceptions and qualifications far outnumber the rule due to the requirements of business. Such exceptions came to be known as innominate contracts. An example is the bay' al-salam or forward sale in which the subject matter does not yet exist but the seller undertakes to make it available at a later date to the purchaser. The non-existent subject matter is a promise given in exchange for immediate payment. According to the rules of sharia, this kind of sale would be unlawful as the seller sales what is not in existence. See Nabil Saleh, 'Definition and Formation of Contract under Islamic and Arab Laws', Arab Law Quarterly 5 (1990) 101-116; Nayla Comair-Obeid, The Law of Business Contracts in the Arab Middle East (London: Kluwer Law International, 1996).
} 
Article 2 of the Commercial Code provides that in the absence of agreement and relevant law, commercial custom and practices are to apply to the matter. Specific customary practices are to have precedence over general custom and where custom is absent civil law applies so long as it does not contradict general commercial principles. ${ }^{26}$ Thus, the sharia, according to the Commercial Code, does not play a role in commercial matters unless commercial custom reflects sharia principles.

In practice, the highest court of the UAE, the Federal Supreme Court, as well as the Dubai Court of Cassation, have upheld Article 2 by enforcing commercial practices that are widely viewed as contraventions of the sharia. ${ }^{27}$ The courts have enforced interest provisions, which the Commercial Code makes lawful. ${ }^{28}$ Article 76 limits the interest rate to 12 per cent. Curiously, however, courts have construed interest charges as compensation for delay rather than strictly enforcing the law. Viewing interest in this manner seems to allow UAE courts to enforce interest provisions without contravening the sharia's prohibition of riba.

The Central Bank's recent adoption of AAOIFI standards, while an important step in standardising Islamic financial practices in UAE domestic markets, is not a panacea for the uncertain role of the sharia in the UAE. Financial institutions dealing in Islamic financial products and services are required to conform to AAOIFI sharia standards in relation to their products and services but courts are not required to consider such standards in their adjudication of financial disputes. Malaysia faced similar challenges in enforcing its central bank-mandated sharia standards in its common law courts.

Prior to the promulgation of the Malaysian Central Bank Act 2009, Malaysia's common law courts were loath to give up jurisdiction in favour of the central bank's Shariah Advisory Council (SAC). ${ }^{29}$ Malaysian legislators solved the problem by including provisions in the Act, which bind the courts to the IFL guidelines and rulings of the SAC. Article 56(1)(a)-(b) provides that 'in any proceeding relating to Islamic financial business before any court or arbitrator, any question arises concerning a shariah matter, the court or the arbitrator, as the case may be, shall (a) take into consideration any published rulings of the Shariah Advisory Council; (b) refer such question to the Shariah Advisory Council for its ruling'. Moreover, article 57 states that 'any ruling made by the Shariah Advisory Council pursuant to a reference made under this Part shall be binding on the Islamic financial institutions under section 55 and the court or arbitrator making a reference under section $56{ }^{\prime} .{ }^{30}$ Therefore, financial disputes that come before Malaysia' courts, which involve the sharia, are decided by the SAC and the court is bound by the SAC's ruling.

Despite UAE courts' general practice, legal ambiguity concerning the role and effect of the sharia in UAE law persists. Courts will likely decide an Islamic finance dispute as they would do so in relation to a conventional financial transaction. However, transactions which employ Islamic nominate contracts may be adjudicated according to the provisions of the Civil Code. The UAE Civil Code requires the court to do so. The Sharjah court was presented with this scenario in relation to the Dana Gas Sukuk dispute but, in May 2018, Dana Gas was able to strike a deal with sukuk holders, which ended the year-long litigation and restructured the debt. ${ }^{31}$ The eventual outcome of these proceedings can only be the subject of guesswork.

\footnotetext{
${ }^{26}$ Federal Law No. 18/1993 Issuing the Commercial Transactions Law (Commercial Code), Art. 2.

${ }^{27}$ See Federal Supreme Court Decisions 591/2012 on 24/09/2013 - UAE 591/2012; and 436/24, 440/24 on 11/10/2005 - UAE 436/24.

${ }^{28}$ Ibid., arts 76-79.

${ }^{29}$ For a good overview of case law concerning Islamic financial disputes see Zulkifli Hasan and Mehmet Asutay, 'An Analysis of the Courts' Decisions on Islamic Finance Disputes' 3(2) (2011) ISRA International Journal of Islamic Finance: 41-71.

${ }^{30}$ Central Bank Act 2009, Art. 56-7.

${ }^{31}$ Robert Smith, 'Dana Gas Strikes Restructuring Deal to End Sukuk Dispute' (London: Financial Times, 13 May 2018) <https://www.ft.com/content/83ace1c2-56a4-11e8-b8b2-d6ceb45fa9d0>.
} 
Sukuk are often referred to as Islamic bonds but their ownership attributes make them more similar to investment certificates. Sukuk (sakk sg.) 'represent[s] a proportional or undivided ownership interest in an asset or pool of assets'.32 Although the sakk has deep historical roots, the modern sukuk's legal structure is modelled after derivatives contracts known as securitisations, while usually replicating the payment and security profile of conventional bonds. ${ }^{33}$ A securitisation enables an originator (company, municipality or government) to raise money from investors on the security of receivables or assets. It represents an increasingly important way of raising finance from investors in open markets instead of through a traditional financial intermediary such as a bank. Investors receive dividends in respect of the assets and the return of their principal investments upon maturity of the sukuk.

There are two types of sukuk: asset-based and asset-backed. Asset-based sukuk are those in which the originator conducts a nominal sale but not a true sale of the underlying assets to the SPV. ${ }^{34}$ In the absence of a true sale, sukuk holders are treated as unsecured creditors of the SPV. Further, the sukuk issuance depends on the credit profile of the originator of the transaction rather than the assets. Almost all sukuk issued to date have been of this type.

Asset-backed sukuk involve the true sale of assets to investors. The credit profile of asset-backed sukuk is based on the assets and the cash flows produced by such assets. Were a loss to arise, sukuk holders would bear the loss as owners of the assets.

Contractual arrangements which ensure that sukuk holders do not have a claim on the underlying assets are prevalent in asset-based sukuk issuances. Known as purchase undertakings, these arrangements require that the SPV must transfer back the asset to the originator upon the redemption of the sukuk or in the event of default. The purchase undertaking provides the SPV with a contractual claim against the originator for nonpayment of the purchase price for the assets, equal to the nominal amount of the sukuk. However, the SPV has no claim against the assets and this places sukuk holders in a position similar as if they were bondholders under a conventional unsecured bond. Therefore, the structure of the sukuk determines the level of protection afforded to investors. ${ }^{35}$

The Dana Gas Sukuk is comprised of US $\$ 425,040,000$ exchangeable certificates and US $\$ 425,040,000$ ordinary certificates, which both became due on 31 October 2017. Both types of certificates are structured as mudaraba sukuk. Periodic distribution amounts were payable by the Trustee on the outstanding face amount of the relevant certificate quarterly. The exchangeable certificates were paid at a rate of 7.0 per cent per annum whereas the

\footnotetext{
${ }^{32}$ McMillen, 'Islamic Capital Markets', supra note 20 at 163.

${ }^{33}$ The classical sakk was an ancient monetary instrument first described in Malik's famous treatise, al-Muwatta. In the first Islamic century the Umayyad Caliphate would pay soldiers and public servants in cash and kind. Sakk holders would produce their certificate upon its maturity date at the treasury and receive a fixed amount of commodity, usually grains. See Mohammed Rafe Haneef, 'Recent Trends and Innovations in Islamic Debt Securities: Prospects for Islamic Profit and Loss Sharing Securities', paper presented at the Harvard University Forum on Islamic Finance. Islamic Finance: Current Legal and Regulatory Challenges, Cambridge, 2005.

${ }^{34}$ There are two general legal thresholds which must be met for a 'true sale' to have taken place. First, the seller should have no liability for the asset except for providing warranties against defects. The seller has no moral duty to note holders to compensate them for any shortfalls. Second, buyers should maintain exclusive control and dominion over the asset, which entitles them to sell or pledge it without consideration of the seller. The sale cannot be revocable upon the insolvency of the purchaser. See Philip R Wood, Project Finance, Securitisations, Subordinated Debt: Law and Practice of International Finance (London: Sweet \& Maxwell, 2007).

${ }^{35}$ Latham \& Watkins, 'The Sukuk Handbook: A Guide to Structuring Sukuk' (Latham \& Watkins, 2015) <https://www.lw.com/thoughtLeadership/guide-to-structurings-sukuk-2015> accessed 17 August 2017.
} 
ordinary certificates received a rate of 9.0 per cent per annum. Ostensibly these distributions derived from the profits of the investment activity and are thus sharia compliant.

Mudaraba sukuk are investment sukuk which represent ownership of units of equal value in the equity of the mudaraba. In a mudaraba or silent partnership the owner of capital (rabb al-mal) gives capital to an investment agent (Mudarib) to trade on their behalf. Profits are shared according to a pre-agreed formula whereas all financial losses are borne by the provider of capital. The Mudarib can only lose her effort if profits do not materialise. A mudaraba may be for any period of time and the contract is liquidated at the end of the period. One of the most important conditions of a mudaraba is that any return results from the performance of the mudaraba and is a ratio of the profit. A fixed amount of profit is an invalid condition because it guarantees a return, which is considered riba. In the mudaraba sukuk certificate holders provide the capital for the sharia compliant investment activity which is undertaken by an investment agent, usually the originator. The investment agent is paid an agreed fee out of any profits derived from the business activity.

The pertinent issue in relation to the Dana Gas Sukuk structure is the scheduled redemption or purchase undertaking in which the Mudarib liquidates the mudaraba assets and repays sukuk holders their capital investments. As noted, a purchase undertaking to buy back the underlying assets from the originator at face value on the 'scheduled redemption date' or in the event of a default indicates that the investors have not assumed the risks of ownership associated with the underlying sukuk assets. The originator has retained true ownership of the assets and thus the credit rating of the sukuk issuance is at the same level as the originator's senior unsecured rating for long term sukuk. ${ }^{36}$ According to the Dana Gas Sukuk prospectus the 'certificates shall be redeemed in full by the Trustee on the Scheduled Redemption Date in cash for an amount equal to the Standard Redemption Amount as at such date. The Trust shall be dissolved only following such payment in full in respect of both the exchangeable certificates and the ordinary certificates. ${ }^{37}$ The 'standard redemption amount' is defined as 'the aggregate principal amount of the exchangeable certificates then outstanding plus all unpaid accrued periodic distribution amounts and all other accrued and unpaid distribution amounts [...]. ${ }^{38}$ Therefore, investors will be compensated in full irrespective of the assets' performance in addition to the regular profit distributions. The issuance offers a similar risk and reward profile as a conventional bond. Hence the market term for such issuances is 'Islamic bond'.

This type of legal structure is market practice in Islamic capital markets. ${ }^{39}$ In 2007 , Sheikh Taqi Usmani (then chairman of the AAOIFI Shariah board) declared that 85 per cent of the sukuk market was not compliant with the sharia. Subsequently, AAOIFI issued a statement in relation to sukuk modelled on the mudaraba and musharaka contracts, which provided that the purchase undertaking 'should not be based on an exercise price which is calculated by reference to the face value of the sukuk at the maturity date or upon the earlier dissolution of a sukuk'. Instead, the purchase undertaking should be based on the 'net asset

\footnotetext{
${ }^{36}$ A number of conditions must be met for this rating. If such conditions are not met, the sukuk issuance is given a lesser rating. For details see Standard \& Poor's Ratings Services, 'Methodology for Rating Sukuk' (Standard \& Poor's, 19 January 2015) < https://www.econostrum.info/attachment/545518> accessed 17 October 2018.

${ }^{37}$ Dana Gas, 'Dana Gas Sukuk Limited' (Offering Circular, 8 May 2013) 18

<http://www.londonstockexchange.com/specialist-issuers/islamic/danagas-prospectus.pdf> accessed 1 August 2017.

${ }^{38}$ Ibid., p. 116.

${ }^{39}$ Neil D Miller, 'Some Considerations When Islamic Transactions Default', Corporate Rescue and Insolvency 7 (2014): 44, 48 .
} 
value, market value, cash equivalent value or any price agree upon at the time of purchase'. ${ }^{40}$ The full value of capital can only be repaid to sukuk holders in the event of negligence or malfeasance. The principle is that sukuk holders bear some of the risk of the underlying assets. Dana Gas's action to have its sukuk issuance declared unlawful in a Sharjah court (UAE) reopens this debate and threatens to undermine the industry. ${ }^{41}$

This is not the first time that a party has sought to invalidate a contract due to its alleged contravention of the sharia. In English law the most authoritative case is Shamil Bank v. Beximco Pharmaceuticals $\mathrm{Ltd}^{42}$ which concerned a financing agreement with a governing law clause that sought to govern the contract according to both sharia and English law. The Court of Appeal's judgment contains two important principles. The first concerns the Rome Convention on the Law Applicable to Contractual Obligations - an EU treaty. The court found that the Rome Convention does not permit a non-state legal order or body of principles to act as the governing law of a contract. Second, the court found that the identification of the sharia in the governing law clause did not meet the criteria of the English doctrine of incorporation. The doctrine allows parties to identify foreign law or non-state legal provisions such as the lex mercatoria or IFL in specific 'black letter' terms of their contract whereby an English court will construe the contract, 'reading into it as if they were written into it the words' of the foreign law. ${ }^{43}$ The effect of such a reading does not make the non-state or other foreign law the applicable law of the contract. Rather, the specific articles of such a law are incorporated as contractual terms into a contract governed by English law. ${ }^{44}$ The court found that 'the general reference to the principles of the sharia ... affords no reference to, or identification of, those aspects of sharia law which are intended to be incorporated into the contract, let alone the terms in which they are framed'. ${ }^{45}$ The court agreed with expert witnesses that the blanket reference in the governing law clause to the sharia does not provide the court with specific terms or rules that could be incorporated into the contract. ${ }^{46}$

The case of The Investment Dar Company $(T I D)^{47}$ illustrates some striking similarities with the Dana Gas case that may prove to be instructive. In that case TID argued that the financing agreement, which its Sharia Supervisory Board (SSB) had approved, was no longer sharia compliant. Therefore, the agreement was ultra vires its articles of association and void under Kuwaiti law. Were a court to rule that a contract had been undertaken ultra vires its articles of association, the contract would be deemed void despite any recitals, contractual representations or promises to refrain from contesting the sharia compliance of the agreement. The court ruled that the ultra vires issue was indeed a triable issue. An argument could be made as to whether the payment of the profit ("interest") element was sharia compliant. However, TID eventually withdrew the case and so the issue was not examined. However, the case hints at the possibility that claims of sharia invalidity may possibly succeed in relation to the contravention of the municipal laws of states, e.g. Kuwait. If this reasoning stands, the Dana Gas action in the UAE should be taken seriously. The Islamic

\footnotetext{
${ }^{40}$ Farmida Bi, 'AAOIFI Statement on Sukuk and its Implications' (Norton Rose Fulbright, September 2008) < http://www.nortonrosefulbright.com/knowledge/publications/16852/aaoifi-statement-on-sukuk-and-itsimplications > accessed 27 July 2017.

${ }^{41}$ While it is difficult to distinguish between the effects of the Global Financial Crisis, which began in 2008, and the subsequent downturn in sukuk issuances, analysts attribute at least part of the decrease to the Usmani statement.

42 [2004] EWCA Civ 19 [1].

${ }^{43}$ Lawrence Collins, Dicey, Morris and Collins on the Conflicts of Laws, vol. II (London: Sweet \& Maxwell, 2006) 1568.

${ }^{44}$ Ibid., 1571.

45 [2004] EWCA Civ 19 [52]

${ }^{46}$ For an in-depth analysis of the case, see Ercanbrack, supra note 1 at 227.

${ }^{47}$ The Investment Dar Company KSCC v. Blom Developments Bank SAL [2009] EWHC 3545 (Ch).
} 
finance industry was spared the worst damage as a result of the agreement reached between Dana Gas and its creditors. Indeed, if the UAE court had proceeded to determine that the Dana Gas Sukuk was invalid under UAE law, the sukuk market and the Islamic finance industry would have suffered considerable damage. Moreover, a contingent credit risk, according to Moody's, would have surfaced, which existing and future sukuk issuers would have needed to countenance. ${ }^{48}$

\section{$3 \quad$ Multiple Governing Laws and Legal Uncertainty}

The dispute between Dana Gas and investors represented by Deutsche Bank was made more complex and uncertain due to the multiple governing laws and municipal courts vying for jurisdiction of the case. The prospectus's governing law clause indicates that that mudaraba agreement, the share pledges and the mortgage are governed by the laws of the UAE and subject to the non-exclusive jurisdiction of the UAE in relation to these aspects of the transaction. Whereas the declaration of trust, the agency agreement, the purchase undertaking, the sale undertaking, the security agreement, the security agency agreement, the ordinary and exchangeable certificates are governed by English law and subject to the nonexclusive jurisdiction of the English courts. A review of recent issuances including some recent defaults indicates that this is market practice for Islamic capital markets. ${ }^{49}$ This legal hybridity is a cause of legal uncertainty. For instance, the courts of England and Wales will enforce a foreign judgment, whereas the UAE will not enforce a foreign judgment where the UAE courts would otherwise enjoy jurisdiction. In particular, this involves disputes in which: the ownership of properties is located in the UAE; proceedings involved a transaction that was made, formed or supposedly formed in the UAE; the dispute related to an event occurring in the UAE. Where the UAE courts have assumed jurisdiction, they will usually apply UAE law irrespective of the governing law chosen by the parties. ${ }^{50}$ The Dana Gas Sukuk prospectus recognises this uncertainty since it warns investors that a foreign court judgment many not be enforced in the UAE or the Sharjah courts. Furthermore, it states that even if a UAE court were satisfied that an 'appropriate connection exists between the relevant transaction agreement and the foreign law', the interpretation of English law 'by a court in the UAE may not accord with the interpretation of an English court'. ${ }^{51}$

In light of UAE courts' reticence to apply governing law clauses in which a foreign law governs the contract to a matter in which UAE courts would otherwise have jurisdiction, the parties' choice of multiple jurisdictions as both a governing law and non-exclusive jurisdiction made the outcome of the dispute more uncertain. While there is no precedent for this type of case, the default event of Dubai World's Nahkeel Sukuk in 2009 provides a similar set of legal facts. In that issuance multiple governing laws including English and UAE law governed aspects of the sukuk issuance. It was also uncertain how UAE courts would deal with legal structures such as the common law trust. However, at the last moment, Abu

\footnotetext{
${ }^{48}$ Jessica Combes, 'Moody's: The Dana Gas Court Case', Moody's, 4 December 2017,

$<$ http://www.cpifinancial.net/news/post/43685/moodys-the-dana-gas-court-case> accessed 8 December 2017.

${ }^{49}$ The following sukuk defaults all contained governing law clauses with multiple governing laws: the 2008 East Cameron Partners sukuk, the 2009 The Investment Dar sukuk and the 2009 Saad sukuk. For an in-depth analysis see Sweder van Wijnbergen and Sajjad Zaheer, 'Sukuk Defaults: On Distress Resolution in Islamic Finance' (Duisenberg School of Finance - Tinbergen Institute, 2013) < https://papers.tinbergen.nl/13087.pdf> accessed 4 August 2017.

${ }^{50}$ John Gaffney, 'Choice of Law and Jurisdiction Provisions in the UAE' (Al Tamimi \& Co, September 2015) $<$ http://www.tamimi.com/en/magazine/law-update/section-11/september-5/choice-of-law-and-jurisdictionprovisions-in-the-uae.html> accessed 11 July 2017.

${ }^{51}$ Dana Gas, supra note 39.
} 
Dhabi stepped in and bailed out Dubai and Dubai World's Nakheel sukuk holders received their principal investments in full. For reasons of similarity, some of the legal issues involved in the Nakheel Sukuk are examined below.

The parties' pursuit of their interests in parallel jurisdictions highlights the legal uncertainty in relation to the use of multiple governing laws in the Dana Gas Sukuk issuance. The London High Court initially ordered Dana Gas to stay the proceedings it had initiated in the Sharjah courts and to have the Sharjah court lift an injunction protecting Dana from investors' claims. ${ }^{52}$ A full hearing of the case by the court was due to take place in late September. ${ }^{53}$ Due to the legal manoeuvring of Dana Gas and its shareholders, the Sharjah court ordered an interim anti-suit injunction which prohibited parties from proceeding with the litigation before the English court until the Sharjah court had decided the case in the UAE. BlackRock, which had not until then been party to the proceedings and thus was not bound by the Sharjah anti-suit injunction, subsequently applied to the English court to be added as a defendant. BlackRock also sought an interim anti-suit injunction which would prohibit Dana Gas and its shareholders from pursuing the Sharjah proceedings. The injunction was issued and continued until 13 November 2017, when the English court finally delivered its judgment. ${ }^{54}$ An analysis of that judgment follows. The dispute has now been resolved in view of the restructuring deal discussed above but it would seem only a matter of time until similar legal issues resurface in a future dispute.

\section{Legal Conflict between the IFL and the Law of Municipal Legal Systems}

It is market practice that English law governs the purchase and sale undertakings of sukuk issuances for the reason that some jurisdictions, including the UAE, may also invalidate this aspect of the transaction. The influence of the sharia is notable in this respect. Articles 693 to 709 of the UAE Civil Code provide for the mudaraba contract. ${ }^{55}$ Article 704 of the UAE Civil Code provides that: ${ }^{56}$

1. The owner of the capital shall alone bear any loss, and any provision to the contrary shall be void.

2. If any of the capital in the mudaraba is lost, that shall be accounted for out of the profits, and if the loss exceeds the profits the balance shall be accounted for out of the capital, and the mudarib shall not be liable therefore.

As highlighted above, the Dana Gas Sukuk issuance contains sale and purchase undertakings which require Dana Gas as both the originator and mudarib of the securitisation to repay sukuk holders their principal investments in full. According to the prospectus,

the Mudarib shall not be entitled to liquidate the Mudarabah Assets unless the proceeds of such liquidation, when aggregated together with the amounts standing to the credit of the Transaction Account and the Reserve Account, is equal to or greater

\footnotetext{
${ }^{52}$ Dana Gas PJSC v. Dana Gas Sukuk Ltd [2017] EWHC 1896 (Comm).

${ }^{53}$ See Dana Gas PJSC v. Dana Gas Sukuk Ltd [2017] EWHC 2340.

${ }^{54}$ In the interim several hearings took place. The procedural course involved with these hearings can be examined further in: Dana Gas PJSC (a company incorporated under the laws of the United Arab Emirates) $v$. Dana Gas Sukuk Limited, Deutsche Trustee Company Limited, Deutsche Bank AG, Commercial International Bank (Egypt) SAE, Blackrock Global Allocation Fund, Inc. [2017] EWHC 2928 (Comm) [31-32].

${ }^{55}$ UAE Civil Code, supra note 27.

${ }^{56}$ Ibid., Art. 704.
} 


\section{than the Redemption Required Amount. ${ }^{57}$}

This provision directly contravenes Art. 704, sections 1 and 2, by requiring the mudarib to repay sukuk holders their initial investments or 'redemption required amount'. The requirement to repay sukuk holders in full, irrespective of any loss, could lead a UAE court to invalidate this aspect of the transaction or to recharacterise the sukuk as a secured loan with a grant of security rather than a true title transfer. Indeed, Dana Gas's claim in the English court proceedings argued that these provisions of the UAE Civil Code render the transaction unlawful. If this claim is correct, proprietary protection is more significant than a contractual arrangement. ${ }^{58}$ The assets would not form part of the estate of Dana Gas. A contractual agreement, on the other hand, would mean that the assets comprise a part of the estate of Dana Gas and the trustee, Dana Gas Sukuk Limited, would be placed on the list of creditors. ${ }^{59}$ Investors could not be certain to retrieve their investments. The English commercial court judgment in relation to the Dana Gas Sukuk, issued on 13 November 2017, highlights the central role of the purchase undertaking highlighted above. The case determined the validity of the Purchase Undertaking under English law. Under English law a Purchase Undertaking is a valid and enforceable contract since it is lawful to guarantee an investment's return. This is the case irrespective of the position of UAE law on the matter. ${ }^{60}$ Dana Gas put forward a number of arguments, which for the sake of simplicity, can be termed the construction argument, the mistake argument, the invalidity of the mudarabah argument and the public policy argument. The court found all of these arguments to be without merit. The court's reasoning centres primarily on the way in which it treated the invalidity and mistake arguments. The court found that Dana Gas's argument that the parties had entered into the Mudarabah Agreement mistakenly because they did not realize that it was unlawful and unenforceable under UAE law had been contemplated in the Purchase Undertaking. ${ }^{61}$ Specifically, the Purchase Undertaking defines a default event as a so-called Dissolution Event under clause 2. Clause 5.1.3, which defines default events, defines Repudiation as: ${ }^{62}$

Either the Obligor or the Mudarib repudiates or challenges the valid, legal, binding and enforceable nature of any, or any part of a, Transaction Document to which it is a party or does or causes to be done any act or thing evidencing an intention to repudiate or challenge the valid, legal, binding and enforceable nature of any Transaction Document to which it is a party.

Furthermore, clause 5.1.4 defines illegality as:

at any time it is or will become unlawful for either the Obligor or the Mudarib to perform or comply with any or all of its obligations under the Transaction Documents to which it is a party, or any of the obligations of either the Obligor or the Mudarib under the Transaction Documents are not, or cease to be legal, valid, binding and enforceable.

\footnotetext{
${ }^{57}$ Dana Gas, supra note 39 at 6.

58 [2017] EWHC 2928 (Comm) [41].

59 Salah, supra note 20 at 28.

${ }^{60}$ [2017] EWHC 2928 (Comm) [47].

${ }^{61}$ The primary reason why the claim of mistake failed is because the doctrine cannot operate if the risk of a mistake has been contemplated by the parties. Ibid [64]. See also Bell v. Lever Bros [1932] AC 161.

62 Ibid., [67-70].
} 
Such an event entitles the Trustee (of the sukuk holders) to exercise its rights under clause 2 of the Purchase Undertaking. Further, the Dissolution Events include a situation where:

at any time it is or will become unlawful for the Trustee to perform or comply with any of its obligations under the Transaction Documents to which it is a party or any of the obligations of the Trustee under the Transaction Documents to which it is a party are not, or cease to be, legal, valid, binding and enforceable.

Therefore, the court, assuming that Dana Gas's claim that the Mudarabah agreement under UAE law was invalid and unenforceable, reasoned that there had been a Dissolution Event. This entitles the Trustee to enforce the Purchase Undertaking. In fact, even if the Mudarabah Agreement is lawful under UAE law, Dana Gas's challenge of the validity of the agreement constitutes a Dissolution Event, entitling the Trustee to exercise its rights under clause 2 of the Purchase Undertaking. ${ }^{63}$

In sum, the court found that the Purchase Undertaking was valid and enforceable under English law. ${ }^{64}$ The judgment is congruent with market expectations and generally strengthens the Islamic finance industry because it highlights the legal enforceability of the sukuk transaction documents. ${ }^{65}$ However, the uncertainty raised by the case has resulted in several issuers amending their sukuk documentation so that it precludes the use of a sharia compliance argument so as to refuse the redemption of sukuk. ${ }^{66}$

\section{$5 \quad$ Security Interests}

A further risk is that a security interest will need to satisfy certain formalities for it to be effective. If the transfer were re-characterised as a loan with security, the transfer would likely not have fulfilled the security requirements with the Land Department or the local municipality of the specific Emirate.

According to the prospectus, Dana Gas secured its obligations in relation to the purchase undertaking by granting a security 'in favour of the relevant Security Agent for the benefit of the Trustee, the Delegate, the Certificate holders, the relevant Security Agent and any Receiver (such security being the "Shared Security"). ${ }^{67}$ A component of the "shared security' is 'a first ranking mortgage over a plot of land in Sharjah adjacent to the Sajaa Gas facilities owned by Sajaa Gas Private Limited Company (the "UAE Mortgage")'. ${ }^{68}$ UAE law requires that a UAE mortgage must be registered at the Sharjah Lands Department (SLD), which is the property registration authority of the Government of Sharjah, for it to take effect and to have priority over any subsequent dealings. Furthermore, the SLD will only register a mortgage in favour of UAE licensed banks or persons. The security agent in this issuance was in fact licensed to operate in the UAE. However, there is an absence of clear judicial or legislative guidance in relation to the security agent arrangements and hence it is uncertain whether the specific terms of the UAE mortgage are enforceable in the UAE. ${ }^{69}$ While this

\footnotetext{
${ }^{63}$ Ibid., [70].

${ }^{64}$ Ibid., [86].

${ }^{65}$ Combes, supra note 51.

${ }^{66}$ Bernardo Vizcaino and Davide Barbuscia, 'MidEast Debt: Sukuk Documents Seek to Reassure Investors After Dana Gas Scare', Reuters, 6 December 2017,

<https://www.reuters.com/article/islamic-finance-sukuk/mideast-debt-sukuk-documents-seek-to-reassureinvestors-after-dana-gas-scare-idUSL8N10607L>, accessed 8 December 2017.

${ }^{67}$ Dana Gas, supra note 39 at 16.

${ }^{68}$ Ibid.

${ }^{69}$ Ibid., p. 64.
} 
type of arrangement is widely followed in relation to financial transactions involving foreign financial institutions, it has not often been tested in UAE courts. ${ }^{70}$ For these reasons, the Dana Gas Sukuk prospectus provides that the security agreement and the security agency agreement are governed by English law. Yet, as discussed, it is unlikely that the UAE courts will enforce the contract according to English law.

Furthermore, UAE courts do not operate according to a system of binding precedents. Each case is treated differently and hence there is an even stronger sense of ambiguity concerning the outcome of this type of case. Judges are afforded wide and unfettered discretion in deciding cases. Legal decisions, including their rationale, are not published or disseminated.

\section{$6 \quad$ Other Legal Gaps}

Dana Gas is incorporated in the UAE and a significant part of its business in terms of revenue is located in the UAE in addition to Egypt and the Kurdistan region of Iraq. In order to be able to enforce a judgment with respect to the assets of Dana Gas, the UAE was chosen as the governing law in relation to the mudaraba agreement, the share pledges and the mortgage. In relation to the other aspects of the transaction including the declaration of trust and the purchase undertaking English law has been chosen to govern the contract.

The trust, an English legal concept, is generally ignored and even rejected in civil law countries including the UAE. ${ }^{71}$ The general reason for this is because the civil law does not permit the division of ownership. There may also be conflicts with traditional doctrines of inheritance and matrimonial property law. Three interests are created in the trust: that of the trustee, who temporarily acquires legal title; that of the beneficiary, who temporarily acquires equitable title; and that of the person who will become owner upon termination of the trust. The division of ownership over time derives from the estate concept in England in which ownership resided in the king. The theory of tenure determined the distribution and retention of lands throughout the kingdom. Holders of derivative rights bestowed by the King or from the King's tenants allowed for the occupation and use of English land. Therefore, tenure and the rights and duties of tenants as opposed to ownership and the rights and duties of owners differentiates the common law from the civil law. ${ }^{72}$ Ownership, strictly speaking, is not a concept of private property law and theory in the common law tradition.

In civil law ownership is a concept that resists fragmentation; transfer of ownership must take place in full or not at all. A functional division between legal and equitable title or

\footnotetext{
${ }^{70}$ Maymoona Talib, 'Collateral Creation in the UAE', Galadari, 29 November 2013, < http://www.galadarilaw.com/articlesandpublications_Details.aspx?id=21>, accessed 18 September 2017. ${ }^{71}$ Despite this rejection, some European civil law jurisdictions have sought to respond to the lack of trust-like institutions, which is seen as a disadvantage in commercial transactions. Structures which have a similar functionality as trusts have been implemented in France, Malta, Hungary and the Czech Republic. Liechtenstein has enacted its own Trust Code of 1926 (amended 2008). Some jurisdictions, such as Luxembourg, which has a well-developed structured finance industry, allows trusts to be used where the issue documents are governed by a law other than Luxembourg law, e.g. English law. Luxembourg, Italy, the Netherlands, Switzerland and Monaco have ratified the Hague Convention on the Law Applicable to Trusts and on their Recognition (1985), which allows trusts governed by foreign law to be established over assets located in the country of recognition for the benefit of said country's beneficiaries and other purposes. For more detail see: Vlastimil Pihera, 'Recognition of Trusts in Civil Law Jurisdictions. Remarks to Case of Olsen v Norway', (World Services Group, 3 December 2014) <https://www.worldservicesgroup.com/blog/practice/post/Recognition-of-trusts-incivil-law-jurisdictions-Remarks-to-case-of-Olsen-v-Norway.aspx > accessed 17 October 2018.

72 John Henry Merryman, 'Ownership and Estate: Variations on a Theme by Lawson', Tulane Law Review 48 (1973-74) 916, 927.
} 
between beneficial and security title simply does not exist. ${ }^{73}$ Property law in the civil law tradition derives from the Justinian Code. The French Revolution reasserted the Roman tradition by eliminating divided property rights which were considered to be undemocratic and a characteristic of feudalism. As a result, the number of restricted property rights was strictly controlled. The so-called numerus clausus theory holds that only a small number of well-defined types of divided interests in property should be permitted, including servitudes on real property, mortgages, and usufructs. Because the trust does not fit within any of the limited types of divided property rights recognised by the civil law, it is considered impermissible. $^{74}$

Although the UAE is a mostly secular, civil law jurisdiction, it was noted above that the UAE constitution and civil code assign an interpretational role to the sharia. The sharia also influences UAE law in less direct, albeit significant ways. It is therefore interesting to note that the Islamic legal structure known as the waqf $f^{75}$ (pious or charitable endowment) is considered to be the forerunner of the English common law trust. ${ }^{76}$ The Hanafi school of Islamic law defined the waqf as: "the detention of the corpus from the ownership of any person, and the gift of its property or usufruct either presently or in the future to some charitable purpose'. ${ }^{77}$ Ownership of the property in the waqf structure was no longer held by the founder, nor did any other person acquire the property beneficially. The true owner of waqf property is God. ${ }^{78}$ Similar to the trust the legal and beneficial title to the property were separated. Ownership and utility were never combined in the same person at the same time. ${ }^{79}$ Despite the similarities between the trust and the waqf, UAE law has abandoned this aspect of the sharia in favour of the civil law.

The Dana Gas Sukuk, like other sukuk issuances in the region, uses English law as the governing law of the trust declaration. There are a number of reasons for the choice of English law. First, the law of some jurisdictions, such as England and New York, are often used in international commercial contracts because there is a substantial body of sophisticated case law dealing with issues which arise in conflicts over commercial or financing contracts. This leads to greater legal certainty and foreseeability for contracting parties. Second, most of the leading law firms drafting sukuk prospectuses are English or western firms with offices across Southeast Asian and GCC countries. Third, stakeholders, including investors, demand that English law is used. Investors demand a formal forum for dispute resolution that is not imperilled by weak regulatory and legal infrastructure. ${ }^{80}$ Finally, English case law regarding leading Islamic finance cases indicates that courts will apply the law in a very practical way. Beximco, one of the cases discussed above, demonstrated the English legal principle whereby the sharia or other non-state body of law can be incorporated as contractual terms in an Islamic financial transaction. The sharia defence, which is often pleaded by the defaulting party or the defendant to persuade the court that the transaction contravenes sharia, has not succeeded with the English courts. The decisions of Beximco and

\footnotetext{
${ }^{73}$ Ibid., pp. 940-41.

${ }^{74}$ Henry Hansmann and Ugo Mattei, 'The Functions of Trust Law: A Comparative Legal and Economic Analysis', New York University Law Review 73 (1998): 434-479, 442.

${ }^{75}$ In the Arabic, the verb waqafa literally means to make a thing stop and stand still. The plural form of waqf is awqaf.

${ }^{76}$ M Gaudiosi, 'The Influence of the Islamic Law of Waqf on the Development of the Trust in England: The Case of Merton College', University of Pennsylvania Law Review 136 (1987-88): 1231-1261.

${ }^{77}$ Paul Stibbard, David Russell \& Blake Bromley, 'Understanding the Waqf in the World of the Trust', Trusts \& Trustees 18 (2012): 785-810, 786.

${ }^{78}$ Ibid.

${ }^{79}$ Ibid., p. 789.

${ }^{80}$ Umar A. Oseni \& M. Kabir Hassan, 'Regulating the Governing Law Clauses in Sukuk Transactions', Journal of Banking Regulation 16 (2015): 220-249.
} 
other cases before the English courts ${ }^{81}$ created legal certainty and foreseeability with respect to the financial and legal practices of the Islamic finance industry.

Because UAE law does not recognise the trust, securitisation, including laws providing for the establishment of special purpose vehicles (SPVs), is normally facilitated through the Dubai International Financial Centre (DIFC). The DIFC provides a legal framework for securitisation. ${ }^{82}$ At present there is no legal framework for the securitisation of assets under Dubai law or UAE law.

The UAE law's less flexible view of ownership was highlighted in the Nakheel Sukuk default event. The structure's sale agreement was to transfer certain real property rights and rights relating to it, from the originator to the SPV. The Nakheel Sukuk, which was a saleand-lease-back structure (sukuk al-ijarah), provided for a transfer of leasehold rights to the SPV. Leasehold rights under UAE law are not always considered as real rights or property rights, depending on the length of the term. In Dubai leases with a term of not more than 10 years are treated as contractual rights while those with a term of 10 years or more constitute a property right. The leasehold interests of the Nakheel Sukuk, with a term of less than 10 years, constituted unregistered contractual rights as opposed to real property rights, making it a lease-and-lease-back transaction. This legal gap is significant since a contractual agreement, in the case of insolvency, provides investors with less protection. A transfer of ownership of real property rights removes the assets from the bankruptcy estate of the originator. The assets of the Nakheel Sukuk special purpose vehicle (SPV) would have been put on the list of creditors of the originator, should the matter have wound up in court. ${ }^{83}$

\section{$7 \quad$ Conclusions}

Islamic financial law is a highly fragmented global legal order, which depends on municipal legal systems for its facilitation and enforcement. Yet the hybrid features of Islamic finance transactions, particularly those transacted in MENA jurisdictions such as the UAE, illustrate a disjuncture between IFL and the municipal law. This contributes to a lack of legal consistency, predictability and transparency as parties' ability to assess and allocate risk is undermined. Some of the primary reasons for this uncertainty are illustrated in the legal and regulatory conflicts, which the dispute involving Dana Gas and its creditors brought forth. These issues seem to have been the impetus for the recent approval of a Higher Sharia Board for Banking and Finance in the UAE. The board, which is an organ of the central bank, will be responsible for rule-setting, standards and general principles for the Islamic finance industry. ${ }^{84}$ The Board's subsequent adoption of AAOIFI standards represents an important step by UAE authorities to shore up confidence in the Islamic finance industry. Yet, mandating AAOIFI standards alone will not produce more certain results if the judiciary is not familiar with and willing to enforce these standards as well as any sharia-related pronouncements of law by the Higher Sharia Board. As was the case with the Malaysian industry-specific legal and regulatory system for Islamic finance, an important reform requires the courts to observe such standards and sharia-related pronouncements. Alas, this is just one of the many reforms that municipal legal systems must undertake to accommodate

\footnotetext{
${ }^{81}$ Including the first Islamic financial transaction disputed in a western court: Islamic Investment Co Ltd v. Symphony Gems NV [2002] ALL ER (D) 171 Transcript.

${ }^{82}$ Rizwan H. Kanji ,'UAE', in Mark Nicolaides (ed.), The International Comparative Legal Guide to: Securitisation 2013 (London: Global Legal Group, 2013) pp. 389-396.

${ }^{83}$ Salah, supra note 20 at 28.

${ }^{84}$ Emirates News Agency, 'UAE Cabinet Approves Establishment of Both UAE Council for Fatwa and Sharia Board for Banking and Finance', 30 May 2017.
} 
IFL. In the interim, the global importance of English law as the proper law of cross-border Islamic finance transactions seems certain to increase.

More country-specific empirical research is necessary to determine the specific nature of legal and regulatory reforms in the municipal legal systems where Islamic finance is facilitated. In the UAE, an important aspect of such research should examine the ways in which UAE courts henceforth adjudicate Islamic financial disputes which involve AAOIFI standards. 